\title{
Resuspension of benthic protists at subtidal coastal sites with differing sediment composition
}

\author{
Jeff Shimeta $^{1, *}$, Carl L. Amos ${ }^{2}$, Stace E. Beaulieu ${ }^{3}$, Stephanie L. Katz ${ }^{1}$ \\ ${ }^{1}$ Biology Department, Franklin \& Marshall College, PO Box 3003, Lancaster, Pennsylvania 17604-3003, USA \\ ${ }^{2}$ School of Ocean and Earth Science, Southampton Oceanography Centre, European Way, Southampton SO14 3ZH, UK \\ ${ }^{3}$ Woods Hole Oceanographic Institution, Woods Hole, Massachusetts 02543, USA
}

\begin{abstract}
Mechanisms and consequences of sediment resuspension are well studied in coastal environments, but the associated resuspension of micro-organisms is poorly understood. Using an in situ flume, and by sampling the benthic boundary-layer during tidal cycles, we measured resuspension of protists and sediment at a subtidal, sandy site in Buzzards Bay, Massachusetts, USA, and compared it to previous studies at a silty site in the bay with similar current magnitude. At the sandy site, where the bottom shear stress typically is greater on flooding than on ebbing tides, resuspension occurred only with the flooding current, whereas at the silty site, where the bottom stress is relatively similar on flooding and ebbing tides, resuspension occurred during both flood and ebb. For sediment and most protistan taxa at the sandy site, erosion thresholds were higher and the total material resuspended in strong flow was lower than at the silty site. At both sites, organic-rich, flocculent surficial sediment resuspended in weak flow, but the composition of the protistan community associated with it differed. At the sandy site it included heterotrophic nanoflagellates (HNan), euglenoid flagellates, oligotrich ciliates, and scuticociliates, whereas at the silty site it included HNan, oligotrich ciliates, and the diatom Navicula distans. Differences in the resuspension thresholds of ciliate groups between sites were due largely to differences in taxonomic composition, whereas differences for diatoms were linked to sediment dynamics. At both sites, protistan taxa resuspended in sequence as flow accelerated, implying that the assemblage of species exchanged between benthic and planktonic communities depends on the maximal bottom stress. At the silty site, however, the composition of this group should be more sensitive to variations in tidal strength (e.g. during the spring-neap cycle) than at the sandy site. Resuspension of protists may have strong impacts on microbial food-web ecology in the water column and sediments by linking the communities and by creating strong fluctuations of cell concentrations (measured up to $24 \times$ in the boundary-layer in the case of oligotrichs). Tidal resuspension of protists is common in the subtidal of Buzzards Bay, but its dynamics depend on local sediment properties, hydrography, and taxonomic composition.
\end{abstract}

KEY WORDS: Resuspension $\cdot$ Protists $\cdot$ Benthic flume $\cdot$ Erosion threshold $\cdot$ Buzzards Bay

\section{INTRODUCTION}

Periodic or episodic resuspension of sediments is a widespread phenomenon in coastal and shelf environments. Such resuspension has strong impacts on sediment transport, chemical fluxes, and biological productivity (Fanning et al. 1982, Demers et al. 1987, Hopkinson 1987, Shaffer \& Sullivan 1988, Maa et al. 1998, Raaphorst et al. 1998). Studies have not only documented patterns of sediment resuspension in the field, but have investigated the dynamics of underlying mechanisms through modeling and experimentation (e.g. Amos et al. 1992a,b, Jago \& Jones 1998, Thomsen \& Gust 2000, Widdows et al. 2000, Sanford \& Maa 2001).

Compared to the present understanding of sediment resuspension, the occurrence, mechanisms, and implications of organism resuspension are poorly known. 
Resuspending organisms can include meiofauna (Suderman \& Thistle 1998), protists such as microalgae (de Jonge \& van Beusekom 1995, Lucas et al. 2001), and bacteria (Ritzrau \& Graf 1992). Currently, the most thorough understanding of organism resuspension concerns microalgae, especially benthic diatoms, the resuspension of which can enhance phytoplankton biomass and productivity, as well as the growth of zooplankton and benthic suspension feeders (Roman \& Tenore 1978, Baillie \& Welsh 1980, Shaffer \& Sullivan 1988, de Jonge \& van Beusekom 1992, Lucas et al. 2001).

Among protists, however, relatively little is understood about the resuspension of protozoa, such as heterotrophic flagellates and ciliates. These cells are known to be integral to microbial food-webs in the water column, and they may be similarly important in benthic food-webs as consumers of microbes, sources of regenerated nutrients, and food for higher trophic levels (Fenchel 1987, Patterson et al. 1989, Caron \&

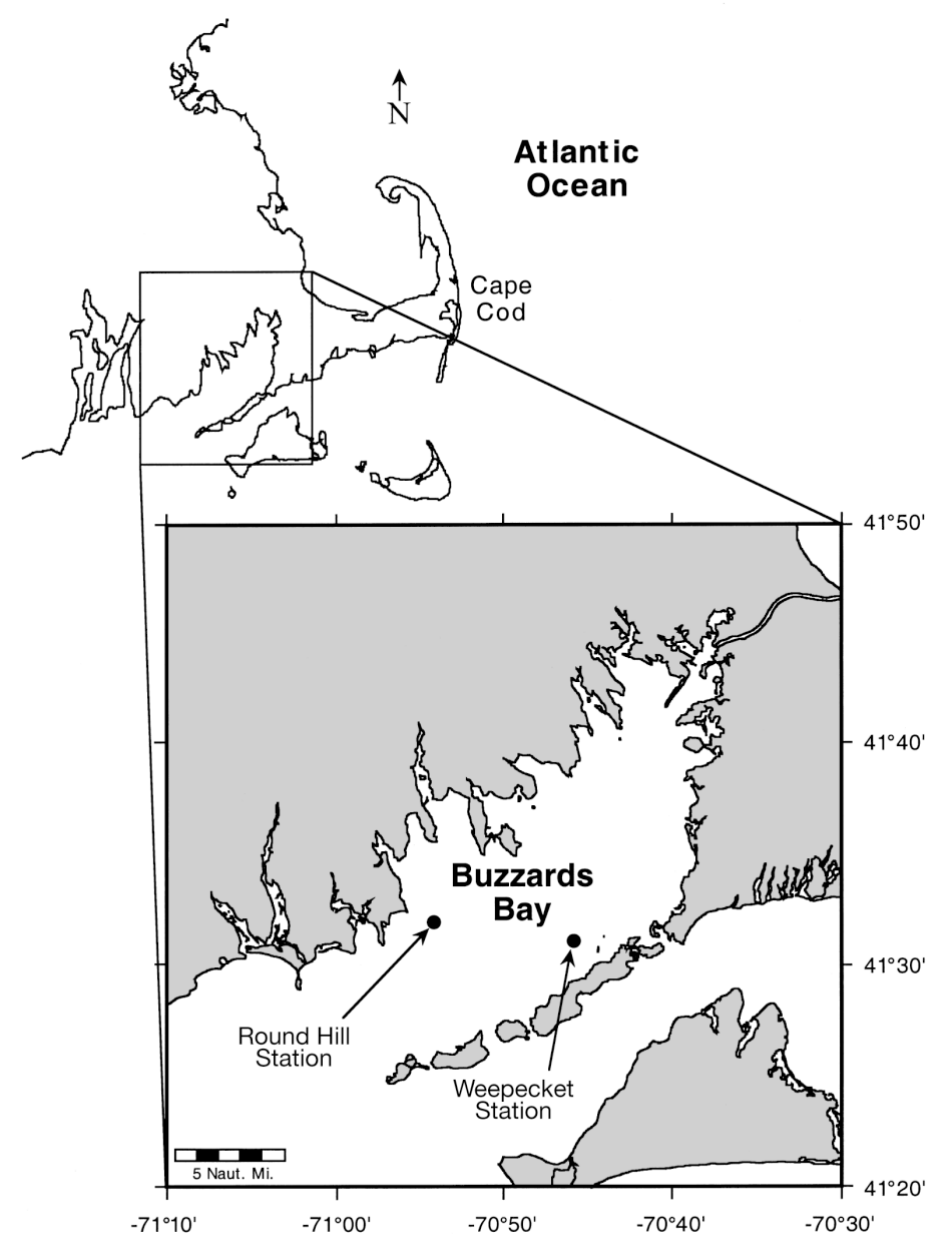

Fig. 1. Study sites in Buzzards Bay, North Atlantic US coast. Coordinates are $41^{\circ} 31.96^{\prime} \mathrm{N}, 070^{\circ} 54.17^{\prime} \mathrm{W}$ at Round Hill Station and $41^{\circ} 31.25^{\prime} \mathrm{N}, 070^{\circ} 45.70^{\prime} \mathrm{W}$ at Weepecket Station
Finlay 1994, Epstein 1997a,b). Recent studies have documented resuspension of protozoa in coastal systems and the importance of benthic boundary-layer flow in both their distributions and feeding rates (Wainright 1987, 1990, Shimeta \& Sisson 1999, Garstecki et al. 2000, Garstecki \& Wickham 2001, Shimeta et al. 2001, 2002). It is unknown whether protozoan resuspension is a widespread phenomenon in coastal systems, or what the roles are of physical-environmental factors (e.g. sediment properties, hydrography) and biological factors (e.g. community structure, cell behavior) in the dynamics of protozoan resuspension.

Here we compare resuspension of protists (including protozoa and microalgae) and sediment at 2 sites in Buzzards Bay, a non-estuarine embayment on the North Atlantic US coast (Fig. 1). The sites are on opposite sides of the bay, of similar depth (14 to $16 \mathrm{~m}$ ) and current magnitude, but dissimilar in their sediment properties. Round Hill Station is in the region of sandy bottom that lines the western side of the bay and extends ca. 3 to 6 nautical miles from the shore (Moore 1963). Weepecket Station is in the silty region that spans most of the central and eastern side of the bay (Moore 1963). Weepecket Station and nearby locations have been sites for numerous studies of sediment geochemistry, resuspension, and infauna (Sanders 1958, Rhoads 1973, Rhoads et al. 1975, Roman 1978, 1980, Roman \& Tenore 1978, McNichol et al. 1988, 1991, Banta et al. 1995). Round Hill Station is near Stn S (Sanders 1958) and Stns 79 and 80 (Moore 1963), and was also the site where sedimentary protozoa were collected for feeding studies by Shimeta et al. (2001).

Resuspension of protists at Weepecket Station was documented by Shimeta \& Sisson (1999) and Shimeta et al. (2002). Here we present new data for both stations, including resuspension measurements at Round Hill involving in situ flume experiments and sampling of the benthic boundary-layer during natural tidal flow. We investigated whether protistan resuspension is common at differing sites in the bay, and whether its dynamics relate to local sediment properties, hydrography, and taxonomic composition of the protistan community.

\section{MATERIALS AND METHODS}

Field sites. To characterize the 2 sites, sediment cores ( $3.8 \mathrm{~cm}$ diameter) were taken by divers at slack low water. Bulk density was determined by x-ray computed tomography of frozen subcores (Amos et al. 1996). For all other analyses, overlying water was removed from sediment cores by Pasteur pipette. Sediment was extruded using a calibrated piston device (Fuller \& Butman 1988), and sliced into depth sections 
of 0 to 2,2 to 5,5 to 10 , and 15 to $20 \mathrm{~mm}$. Grain-size distributions were determined by wet sieving into size fractions and weighing dry. Porosity was measured by weighing the sediment before and after drying to determine water content and converting to volume fraction. Particulate organic matter (POM) was measured as the difference in dry weight before and after ashing at $450^{\circ} \mathrm{C}$ for $5 \mathrm{~h}$, corrected for salt content. Chlorophyll a $(\mathrm{chl}$ a) was measured on a Turner Designs fluorometer, after extracting in $90 \%$ acetone (Parsons et al. 1984). Sediment sections for cell counts were preserved with ice-cold $1 \%$ final glutaraldehyde and kept refrigerated until examination.

At each site, an instrument tripod was deployed with an InterOcean S4 current meter mounted at $1.2 \mathrm{~m}$ above the sea bottom and a horizontal SeaTech transmissometer (5 cm light path), ParoScientific pressure sensor, and TattleTale data logger mounted at $0.75 \mathrm{~m}$ above the sea bottom. The tripod was positioned to avoid being directly upstream or downstream of the sampling coordinates at water or sediment collection times. Friction velocity $\left(u_{*}\right)$ was estimated as $u_{*}=$ $\left(C_{\mathrm{D}}\right)^{1 / 2} u$, where $u$ is time-averaged $(1 \mathrm{~min})$ horizontal flow speed and $C_{\mathrm{D}}$ is a drag coefficient $\left(2.9 \times 10^{-3}\right.$; Sternberg 1968). $u_{*}$ relates to bed shear stress $\left(\tau_{\mathrm{b}}\right)$ as $u_{*}=\left(\tau_{\mathrm{b}} / \rho\right)^{1 / 2}$, where $\rho$ is the density of seawater. $u_{*}$ values neglect any contribution from wave stress; therefore, comparisons with $u_{*}$ in the Sea Carousel must be considered approximate. Wave action was minimal at times of sample collection, so any underestimation of bottom stress should be minor.

Sampling throughout the tidal cycle. To document the cycle of cell resuspension, we sampled the benthic boundary-layer and sediments at Round Hill Station on 10 August 1998 (spring tides) during slack high water, ebbing flow, slack low water, and flooding flow using methods similar to those employed at Weepecket Station in 1996 (Shimeta \& Sisson 1999). The benthic boundary-layer sampler is a $1 \mathrm{~m}$ tall, rectangular aluminum frame with a $1 \mathrm{~m}$ diameter, circular base plate that sits flush on the bed, positioned by divers so that its intake nozzles face into the flow. The intake openings are positioned $24 \mathrm{~cm}$ behind the leading edge of the base plate and were slightly modified for this deployment. Four circular nozzles $(0.9 \mathrm{~cm}$ inner diameter) were centered at $100,50,20$, and $5 \mathrm{~cm}$ above the base plate, and a nozzle with a rectangular opening $(2.2 \mathrm{~cm}$ wide $\times 0.5 \mathrm{~cm}$ high $)$ was centered at $0.75 \mathrm{~cm}$ above the base plate. Water samples were drawn simultaneously through all intake nozzles by a Remote Access Sampler (McLane Research Labs), a programmable underwater pump and an array of sample bags, which were connected to the boundary-layer sampler by 5 lines of silicone tubing $(0.6 \mathrm{~cm}$ diameter). At each sampling time, 3 replicate sets of samples were taken in immediate succession. Flow rate through each line was $100 \mathrm{ml} \mathrm{min}^{-1}$, producing entrance velocities of $2.6 \mathrm{~cm} \mathrm{~s}^{-1}$ in the circular nozzles and $1.5 \mathrm{~cm} \mathrm{~s}^{-1}$ in the rectangular nozzle, and a Reynolds number of 354 for flow in the tubing (thus laminar). Samples of $225 \mathrm{ml}$ were pumped into sample bags prefilled with ice-cold glutaraldehyde ( $1 \%$ final), and they were kept refrigerated until cells were counted. The lines were flushed between samples. At each sampling time, divers collected sediment cores, which were processed as described above. In addition, a vertical profile of the water column was taken with a Sea-Bird SEACAT CTD fitted with a SeaTech transmissometer $(25 \mathrm{~cm}$ path length).

Resuspension experiment. To determine resuspension thresholds experimentally, we resuspended sediment and microbes at Round Hill Station on 11 August 2000 with an in situ flume, the Sea Carousel (Amos et al. 1992b), using methods similar to those employed at Weepecket Station several days earlier (Shimeta et al. 2002). The aluminum Sea Carousel has an outer diameter of $2 \mathrm{~m}$, a channel width of $15 \mathrm{~cm}$, and a height of $30 \mathrm{~cm}$. Flow is driven by a rotating lid with 8 small paddles underneath, and lid speed is measured with a shaft-end encoder and converted to $u_{*}$ using laboratory calibrations for rough boundaries (Amos et al. 1992a). Two optical back-scatter (OBS) sensors are positioned inside the channel at 3 and $18 \mathrm{~cm}$ above the sea bed, and 3 vertically arranged sampling ports are located in the outer channel wall. The Sea Carousel was gently lowered from the RV 'Asterias' onto the sea bed at slack low water. After $30 \mathrm{~min}$, lid rotation began and the rate was increased incrementally every $5 \mathrm{~min}$. Water samples were collected immediately before flow initiation and $2 \mathrm{~min}$ after each speed increase. Tubing was flushed before each sample was taken. At each time point, 1 sample for suspended particulate matter (SPM), POM, and chl a was collected from a port at $5 \mathrm{~cm}$ above the bed with $0.6 \mathrm{~cm}$ diameter rubber tubing and a foot pump on deck. Samples were filtered onto precombusted GF/F filters (Whatman, nominal pore size $0.7 \mu \mathrm{m}$ ), and those for SPM and POM were rinsed with reverseosmosis water. SPM was measured as total dry mass per volume of water sampled; POM and chl a were measured as described above. One water sample for measuring cell concentrations was pumped to the boat's deck at each time point from a port at $10 \mathrm{~cm}$ above the sea bed with $0.6 \mathrm{~cm}$ diameter silicone tubing using a peristaltic pump operating at $500 \mathrm{ml} \mathrm{min}^{-1}$ (tubing Reynolds number of 1770, thus laminar). Samples for cell counts were preserved as described above. At slack low water, sediment cores were collected outside the Sea Carousel by divers and processed as described above. 
Sampling during tidal acceleration. To determine resuspension thresholds under natural tidal flow, we sampled the benthic boundary-layer at Round Hill Station on 31 August 2000 (spring tide) every $15 \mathrm{~min}$ during a single tidal acceleration (flooding tide), using methods similar to those employed at Weepecket Station the 2 previous days (Shimeta et al. 2002). Only 3 of the circular intake nozzles were used on the boundary-layer sampler, and they were all centered at $5 \mathrm{~cm}$ above the base plate, separated from each other by $15 \mathrm{~cm}$ in the horizontal plane. Samples from the 3 replicate nozzles were pumped simultaneously at each sample time through 3 lines of silicone tubing ( $0.6 \mathrm{~cm}$ diameter) to the deck of the RV 'Asterias' using a peristaltic pump. Flow rate was adjusted from $215 \mathrm{ml}$ $\mathrm{min}^{-1}$ at slack water to $500 \mathrm{ml} \mathrm{min}^{-1}$ at peak flow, producing nozzle-entrance velocities of 5.6 to $13.1 \mathrm{~cm} \mathrm{~s}^{-1}$ and tubing Reynolds numbers of 762 to 1770 . The lines were flushed between samples. As described above, samples for cell counts were preserved, additional samples were taken at each time point for measuring and processing SPM, POM, and chl $a$, and at slack low water, sediment cores were collected by divers and processed.

Analyses of cell concentrations. To count heterotrophic bacteria, samples were sonicated for three 1 min bursts with $0.01 \%$ Triton X-100. Sediment samples were diluted 1:5000 with $0.2 \mu \mathrm{m}$ membrane-filtered seawater prior to sonication; water samples were undiluted. Cells were filtered onto $0.2 \mu \mathrm{m}$ black Nuclepore filters, stained with $20 \mu \mathrm{g} \mathrm{ml}^{-1}$ DAPI, mounted on microscope slides with immersion oil, and counted at $1000 \times$ on an epifluorescence microscope under UV excitation (Porter \& Feig 1980). To count nanoflagellates, water samples were filtered onto $0.8 \mu \mathrm{m}$ filters, stained and counted similarly. Presence of photosynthetic pigment was determined by the autofluorescence of chlorophyll under blue excitation. Nanoflagellates were extracted from sediment samples by Percoll-gradient centrifugation (Shimeta \& Sisson 1999) prior to filtration and staining. To count ciliates and pennate diatoms, water samples were settled in $100 \mathrm{ml}$ Utermöhl chambers (Utermöhl 1958) for $48 \mathrm{~h}$ with $0.004 \%$ Nigrosin Black and examined at $630 \times$ in an inverted compound microscope with phase contrast. Extracted sediment samples were each settled for $5 \mathrm{~d}$ after adding the Percoll supernatant from 1 extraction to an Utermöhl chamber and diluting to $100 \mathrm{ml}$ with deionized water and Nigrosin Black.
Vertical profiles of cell concentrations in the benthic boundary-layer and in sediment were each tested by 2 -factor, repeated-measures analysis of variance (ANOVA). Height above bottom or depth in the sediment was the repeated factor, and tidal stage was the second factor; sample size for each combination of height/depth and tidal stage was 3 replicate water samples or sediment cores. For the boundary-layer sampling during tidal acceleration, differences in mean cell concentrations $(n=3)$ among time points were deemed significant if $95 \%$ confidence intervals failed to overlap. For Sea Carousel results, threshold values of friction velocity for resuspension $\left(u_{*_{\text {crit }}}\right)$ were calculated by linear regression of concentration against $\log \left(u_{*}\right)$ in the region where concentration increased monotonically (Sutherland et al. 1998). The $u_{*}$ at which the regression intercepted the initial sample concentration (prior to flow initiation) was taken as $u_{* \text { crit }}$. Cumulative masses of resuspended material or numbers of resuspended cells were calculated as the measured increase plus the estimated loss during each flow increment due to leakage from the flume (Amos et al. 1992b).
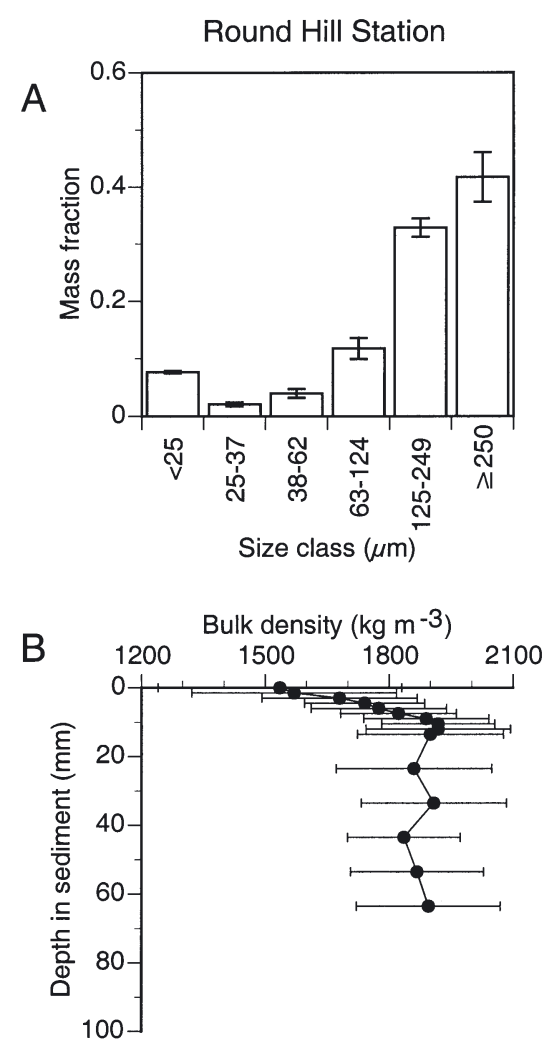

Fig. 2. Sediment characteristics at the 2 sites. (A) Grain-size distribution in surficial $2 \mathrm{~mm}$ (mean $\pm \mathrm{SE}, \mathrm{n}=4$ at Round Hill, $\mathrm{n}=8$ at Weepecket). Data for Weepecket from Shimeta \& Sisson (1999). (B) Bulk density profiles of sediment cores measured by x-ray tomography. Mean $\pm \mathrm{SD}$ derived from ca. 14000 measurements of each tomographic slice; thus, SD reflects

ca. 14000 measurements of each tomographic slice; thus, SD
sediment heterogeneity rather than measurement error
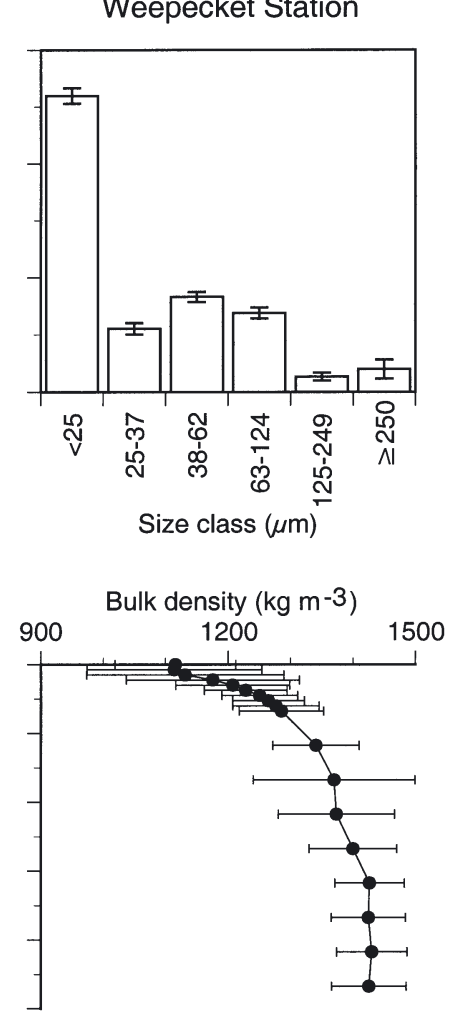


\section{RESULTS}

\section{Sediment and hydrography at the sites}

The grain-size distribution of the surficial $2 \mathrm{~mm}$ at Round Hill Station was distinctly bimodal, dominated by fine and coarse sand, with a smaller peak of silt (Fig. 2A). In contrast, surficial sediment at Weepecket Station was much siltier and essentially unimodal, dominated by $>50 \%$ silt by mass (Fig. 2A). Bulk densities were much higher at Round Hill Station (Fig. 2B). Both stations showed increasing density with depth until a layer of constant density was reached. However, the density gradient was confined to a narrower zone at Round Hill $(10 \mathrm{~mm})$ than at Weepecket $(70 \mathrm{~mm})$, and porosities in the top $2 \mathrm{~mm}$ were also much lower at Round Hill $(73.5 \pm 1.1 \%, \mathrm{n}=3)$ than at Weepecket $(93.5 \pm 2.9 \%, \mathrm{n}=3)$.

Near-bottom flow at both sites during spring tides with the moon in perigee was dominated by a tidal periodicity and counter-clockwise rotation of currents (Fig. 3). Maximal current strength was similar at the 2 sites. At Round Hill, however, flooding currents were usually almost twice the strength of ebbing currents, while at Weepecket the difference between the 2 directions typically was less. Both stations also showed periodicities in near-bottom turbidity, although the patterns differed distinctly (Fig. 3). At Round Hill, light transmittance typically dropped during low tide and rose during high tide. In contrast, light transmittance at Weepecket dropped during every slack-water period (both low and high tides), and it reached a maximum during every peak tidal flow between.

\section{Sampling throughout the tidal cycle}

On the day of sampling the benthic boundary-layer and sediment at Round Hill Station during a complete tidal cycle, flooding currents were quite strong, reaching $u_{*}=2.0$ and $1.7 \mathrm{~cm} \mathrm{~s}^{-1}$, while ebbing currents did not exceed $u_{*}$ $=1.2 \mathrm{~cm} \mathrm{~s}^{-1}$ (Fig. 4). Near-bottom light transmittance during our 4 sampling times showed the typical pattern of high values at slack high tide, followed by a decrease throughout the remainder of the cycle (Fig. 4). Light transmittance did not increase much again until after the peak flooding current. Density profiles of the water column showed little change among the 4 sampling times, but vertical profiles of light transmittance changed dramatically (Fig. 5). Light transmittance at the surface remained relatively constant, while the near-bottom gradient increased at successive sampling times, with flooding water being the most turbid. The 2 transmissometers (moored and profiled) agreed in the relative values among the sampling times at $1 \mathrm{~m}$ above bottom (compare Figs. 4 \& 5).

Statistically significant differences in boundary-layer cell concentrations among tidal stages were found for heterotrophic nanoflagellates (HNan), euglenoid flagellates, total ciliates, and total pennate diatoms (Fig. 6, Table 1). The 2 flagellate groups also showed significant differences among tidal stages in the sediment, while the ciliates and diatoms yielded statistically non-significant

.
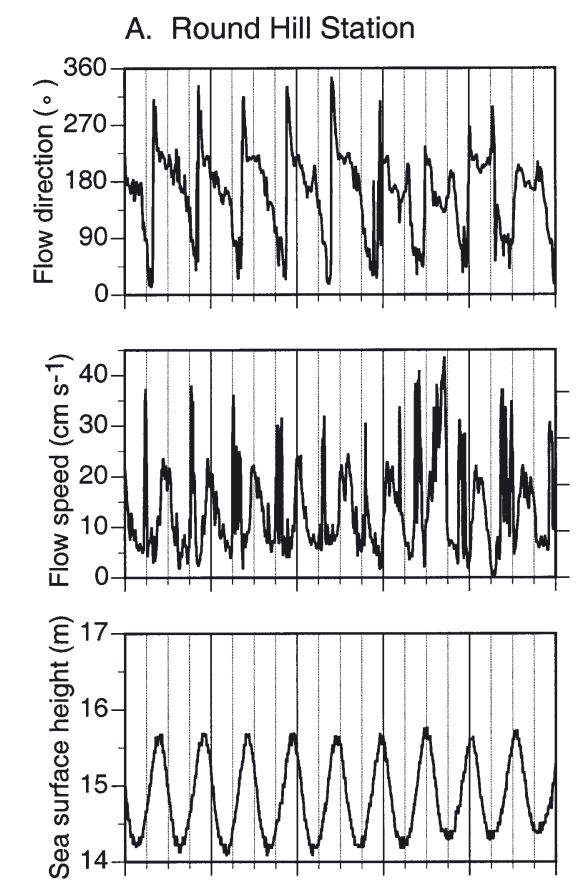

\section{B. Weepecket Station}
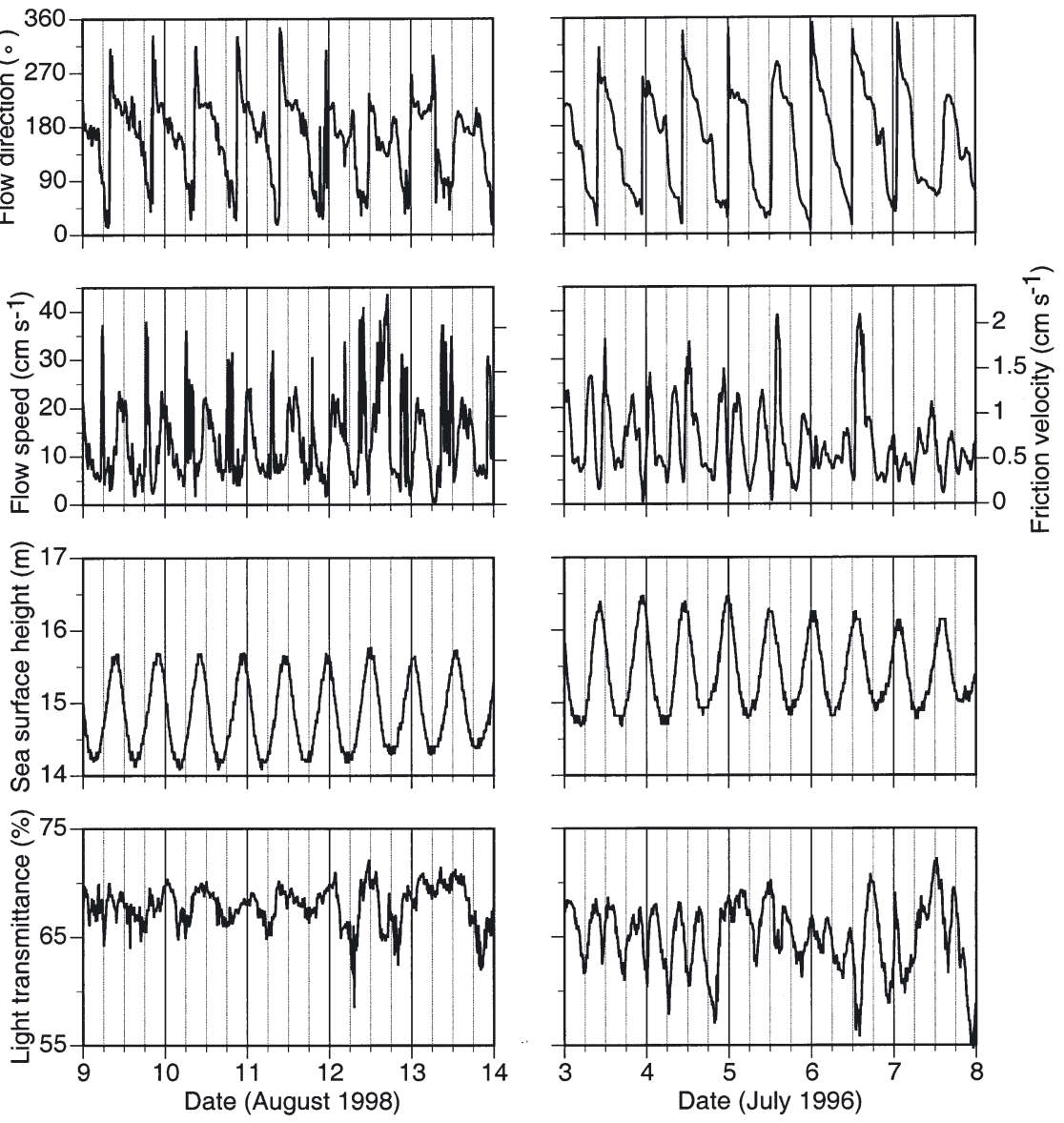

Fig. 3. Flow direction, flow speed and friction velocity, sea-surface height, and light transmittance measured with instruments moored ca. $1 \mathrm{~m}$ above the sea bottom during spring tides with the moon in perigee. An abbreviated portion of Weepecket data set was published in a different form in Shimeta \& Sisson (1999), and Round Hill friction velocity is from Shimeta et al. (2001). Light transmittance was corrected (detrended) for fouling of the instrument over time 

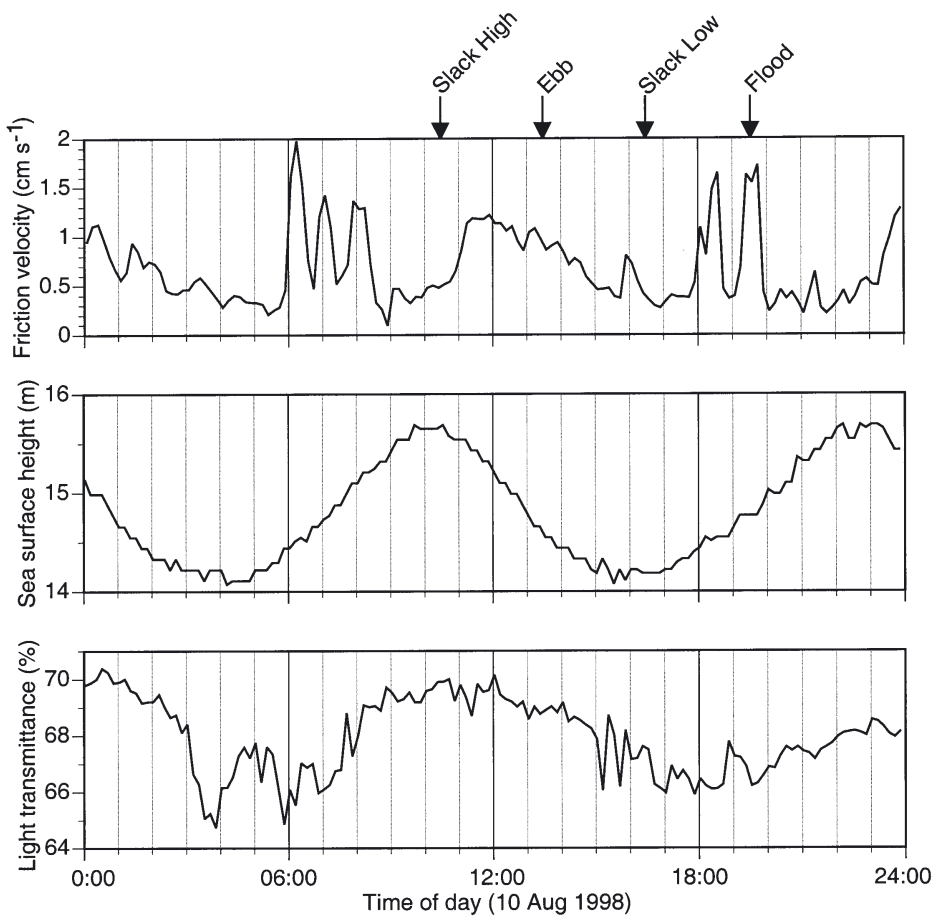

Fig. 4. Enlargement of Round Hill data (see Fig. 3) for 10 August 1998, when the benthic boundary-layer and sediments were sampled for protists throughout the tidal cycle. Arrows on the top panel indicate sampling times earlier peak at $u_{*}=0.19 \mathrm{~cm} \mathrm{~s}^{-1}$ (Fig. 8A), suggesting resuspension of organic-rich material. This peak was followed by a decline of \%POM as the total SPM rose, due to an increasing fraction of heavy mineral grains in suspension. The threshold for chl a resuspension was similar to that for total SPM (Fig. 8A, Table 2).

HNan, bacteria, oligotrich ciliates, and scuticociliates all resuspended soon after the POM peak, with $u_{* \text { crit }}$ in the range of 0.28 to $0.36 \mathrm{~cm} \mathrm{~s}^{-1}$ (Fig. 8B,C, Table 2). The diatoms Navicula distans, N. transitans, Pleurosigma sp., and at least 2 unidentified species of Nitzschia resuspended in stronger flow, with $u_{* \text { crit }}$ in the range of 1.45 to $2.10 \mathrm{~cm} \mathrm{~s}^{-1}$, thus similar to the total SPM and chl a (Fig. 8D, Table 2). PNan and hypotrich ciliates did not resuspend in flow up to $u_{*}=3.2 \mathrm{~cm} \mathrm{~s}^{-1}$ (Fig. 8B,C). All of the aforementioned taxa were included in the analysis because they resuspended at Weepecket Station (Shimeta et al. 2002), in some cases with quite different thresholds (Table 2). Taxa were all abundant in the surficial $2 \mathrm{~mm}$ of sediment at Round Hill Station on the day of the experiment (Table 3). Note, however, that euglenoid flagellates, which resuspended in the tidal-cycle sampling (Fig. 6C), were not detectable in the sediment or in the Sea Carousel on the day of this experiment (Table 3). Resuspension thresholds measured in the trends (Fig. 6, Table 1). In the cases of HNan, euglenoids, and ciliates, the boundary-layer concentrations were higher during flooding tide and slack high water than during the other sampling times. Accordingly, concentrations in the top $2 \mathrm{~mm}$ of sediment were lowest during flooding and slack high water. These observations are consistent with resuspension from the sediment to the boundarylayer during the strong flooding currents shown in Fig. 4. Such a pattern is not clearly evident in the pennate diatoms, and there were no significant differences among tidal stages for pigmented nanoflagellates (PNan; Fig. 6).

\section{Resuspension experiment}

As friction velocity in the Sea Carousel increased stepwise, the continuous OBS readings registered a rise in SPM beginning at $u_{*}=1.7 \mathrm{~cm} \mathrm{~s}^{-1}$ (Fig. 7). Sediment displayed Type I erosion, resuspending in discrete amounts, rather than continuously, following each increase of $u_{*}$. SPM filtered from water samples in the flume channel increased at the same flow increment (Fig. 8A), and the calculated resuspension threshold ( $u_{* \text { crit }}$ ) was $1.79 \mathrm{~cm} \mathrm{~s}^{-1}$ (Table 2). The fraction composed of POM showed a much
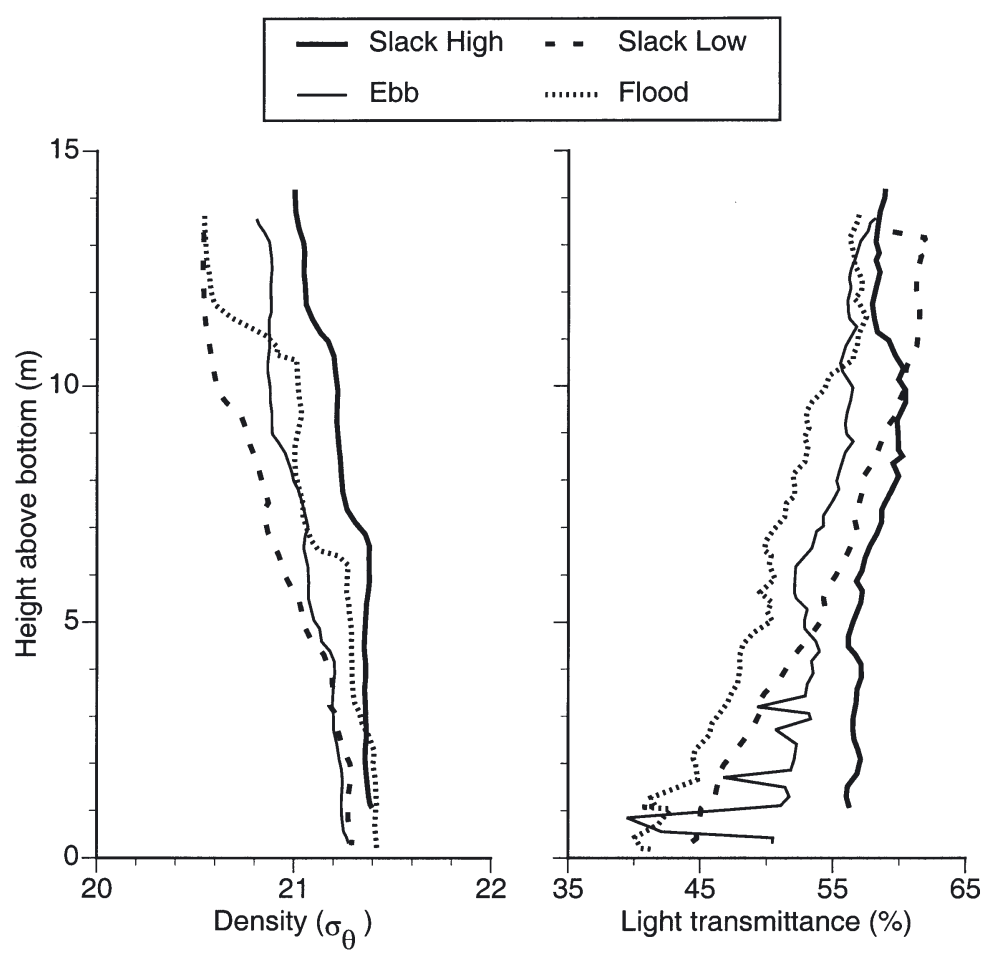

Fig. 5. Water-column profiles of density and light transmittance at Round Hill on 10 August 1998, when protists were sampled throughout the tidal cycle. Sampling times correspond to those indicated in Fig. 4 

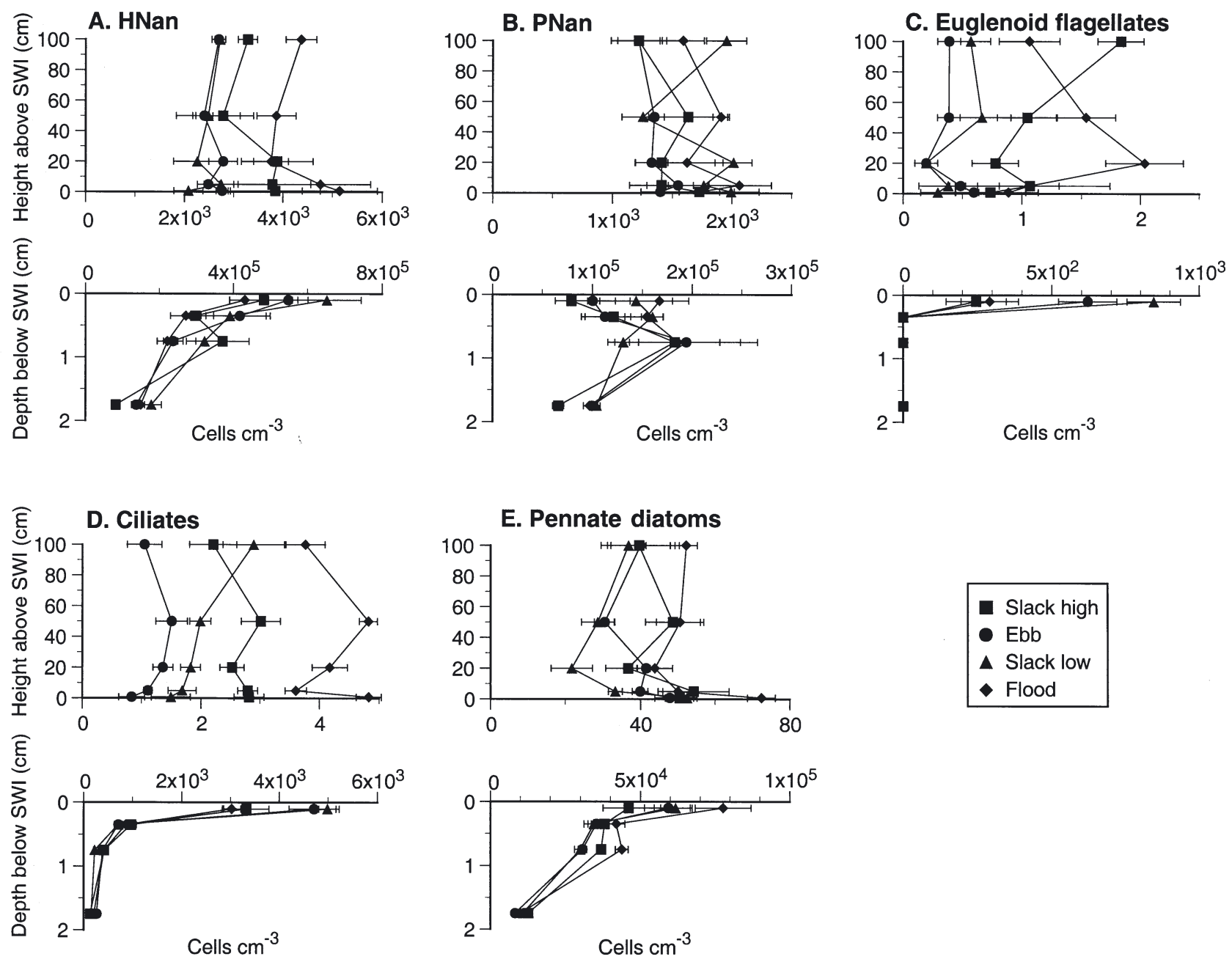

Fig. 6. Profiles of protists in the benthic boundary-layer and sediment at Round Hill on 10 August 1998. Sampling times correspond to those indicated in Fig. 4. Each protistan group includes 2 panels showing cell concentration (mean per unit of water volume or of sediment volume $\pm \mathrm{SE}, \mathrm{n}=3$ ) against distance above or below the sediment-water interface $(\mathrm{SWI})$. HNan $=$ heterotrophic nanoflagellates; PNan = pigmented nanoflagellates

Table 1. p-values from ANOVA on cell concentrations measured in the benthic boundary-layer and sediment throughout the tidal cycle at Round Hill Station (Fig. 6). ${ }^{*}$ Statistically significant at $\alpha=0.05$. HNan $=$ heterotrophic nanoflagellates; PNan = pigmented nanoflagellates

\begin{tabular}{|lccccc|}
\hline & HNan & PNan & $\begin{array}{c}\text { Euglenoid } \\
\text { flagellates }\end{array}$ & Ciliates & $\begin{array}{c}\text { Pennate } \\
\text { diatoms }\end{array}$ \\
\hline $\begin{array}{l}\text { Benthic boundary layer } \\
\text { Tidal stage }\end{array}$ & $0.001^{*}$ & 0.096 & $<0.001^{*}$ & $<0.001^{*}$ & $<0.001^{*}$ \\
$\begin{array}{l}\text { Height } \\
\text { Tidal stage } \\
\times \text { Height }\end{array}$ & 0.54 & 0.49 & 0.31 & 0.15 & $<0.001^{*}$ \\
$\begin{array}{l}\text { Sediment } \\
\text { Tidal stage }\end{array}$ & 0.86 & 0.27 & 0.056 & $0.018^{*}$ & 0.30 \\
$\begin{array}{l}\text { Depth } \\
\text { Tidal stage } \\
\times \text { Depth }\end{array}$ & $0.030^{*}$ & 0.45 & $<0.007^{*}$ & $<0.063$ & $<0.070$ \\
& 0.46 & $0.011^{*}$ & $<0.001^{*}$ & $<0.001^{*}$ & $<0.001^{*}$ \\
\hline
\end{tabular}

Sea Carousel at Round Hill were generally consistent with the results obtained there by sampling throughout the tidal cycle (Fig. 6).

For each site, we calculated cumulative resuspension of SPM, chl $a$, and cells during the Sea Carousel experiments. Calculations were done up to high values of $u_{*}$ that were as similar as possible between sites $u_{*}=3.2 \mathrm{~cm}$ $\mathrm{s}^{-1}$ at Round Hill and $2.9 \mathrm{~cm} \mathrm{~s}^{-1}$ at Weepecket, Table 2). Cumulative resuspension of sediment (measured as SPM) was lower at Round Hill, corresponding to its higher resuspension threshold compared to Weepecket. Similarly, cumulative resuspension of 


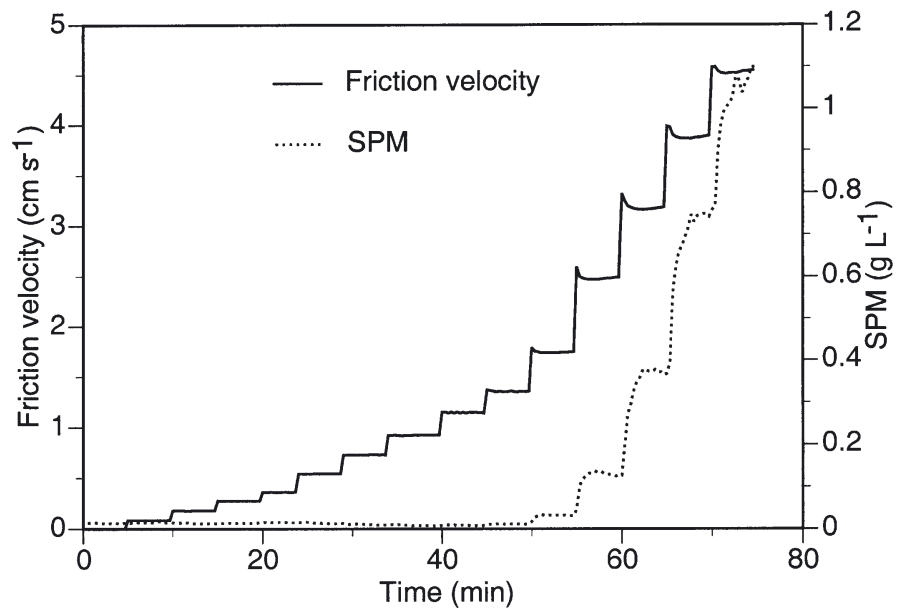

Fig. 7. Friction velocity and suspended particulate matter (SPM) as functions of time in Sea Carousel channel at Round Hill on 11 August 2000. SPM was corrected for leakage from the flume

chl $a$ and cells at Round Hill were generally lower than the cumulative resuspension at Weepecket.

\section{Sampling during tidal acceleration}

While sampling the boundary-layer at Round Hill Station every 15 min during a single tidal acceleration, the flooding current reached a maximum of $u_{*}=1.1 \mathrm{~cm}$ $\mathrm{s}^{-1}$ (Fig. 9A). Concentrations of chl $a$ and SPM sampled at $5 \mathrm{~cm}$ above the sea bottom showed little variation during this time, corresponding with their resuspension thresholds measured in the Sea Carousel (Table 2). \%POM, however, mirrored the flow strength, decreasing during deceleration and increasing by a factor of 2 during acceleration (Fig. 9B). POM first increased at $u_{*}=0.19 \mathrm{~cm} \mathrm{~s}^{-1}$ (the same value at which it increased in the Sea Carousel, Fig. 8A), and peaked at $u_{*}=0.37 \mathrm{~cm} \mathrm{~s}^{-1}$. Statistically significant variation over time was also found for bacteria, HNan, euglenoid flagellates, oligotrich ciliates, and scuticociliates (Fig. 9B-D). Concentrations of these taxa rose simultaneously when $u_{*}=0.37 \mathrm{~cm} \mathrm{~s}^{-1}$, except for the bacteria, which increased after $u_{*}$ had reached $0.61 \mathrm{~cm} \mathrm{~s}^{-1}$. In contrast, concentrations of PNan, hypotrich ciliates, and pennate diatoms showed no significant variations during the sampling (Fig. 9C-E). These apparent thresholds for resuspension under natural flow agreed well with those measured in the Sea Carousel (Table 2), except for bacteria. All of these taxa were abundant in the surficial sediment at Round Hill Station on the sampling day during tidal acceleration (Table 3). Note that euglenoid flagellates, which had been undetectable on the day of the Sea Carousel ex- periment, were abundant on this day of sampling; their resuspension threshold is listed in Table 2, based on the results in Fig. 9C.

The apparent resuspension had large impacts on the cell concentrations measured in the benthic boundary-layer. From the minimal concentration at slack water to the maximal concentration during flooding flow, cell concentration increased by a factor of 24.0 for oligotrichs, 12.9 for euglenoids, 7.2 for scu-
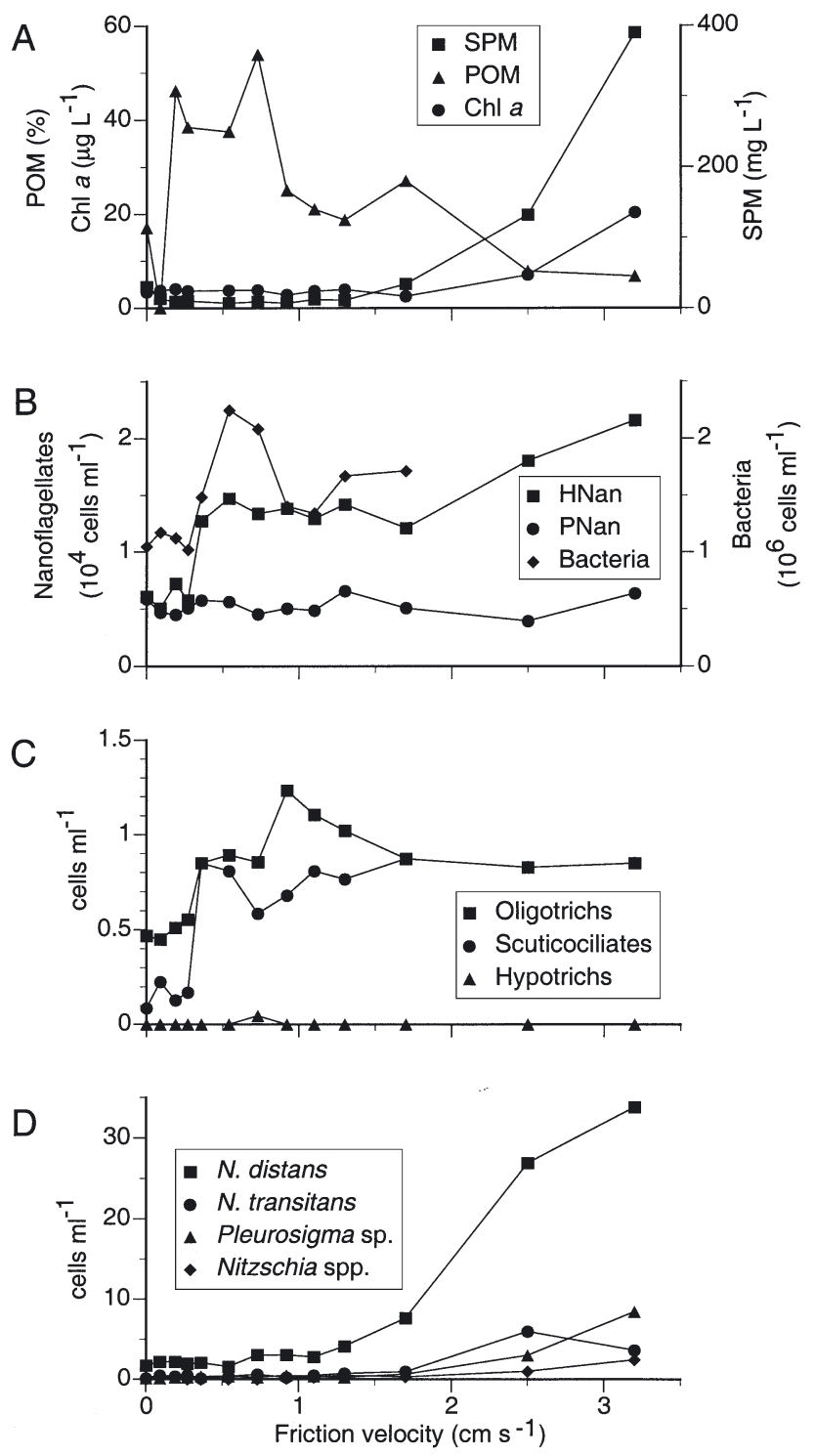

Fig. 8. Measurements on water from Sea Carousel channel at each incremental flow setting at Round Hill on 11 August 2000. (A) Suspended particulate matter (SPM), fraction composed of particulate organic matter (POM), and chl a. (B) Nanoflagellates and bacteria. HNan = heterotrophic nanoflagellates; PNan = pigmented nanoflagellates. (C) Ciliates. (D) Diatoms. Taxonomic groups showing no evidence of resuspension are excluded 
Table 2. Resuspension thresholds and cumulative resuspension in Sea Carousel experiments. Round Hill thresholds calculated by regression analysis of data in Fig. 8 except for HNan, oligotrich ciliates, and scuticociliates (step-function increases, assessed visually) and euglenoids (taken from Fig. 9). Cumulative resuspension is total material resuspended during Sea Carousel experiment up to $u_{*}$ indicated. Weepecket thresholds and resuspension calculated from Shimeta et al. (2002); threshold for Navicula distans is from boundary-layer sampling, all others from Sea Carousel. HNan = heterotrophic nanoflagellates; PNan = pigmented nanoflagellates; nd $=$ not detectable

\begin{tabular}{|c|c|c|c|c|}
\hline & \multicolumn{2}{|c|}{$\begin{array}{c}\text { Resuspension threshold } \\
u_{*_{\text {crit }}\left(\mathrm{cm} \mathrm{s}^{-1}\right)}\end{array}$} & \multicolumn{2}{|c|}{ d Cumulative resuspension ${ }^{a}$} \\
\hline & $\begin{array}{c}\text { Round } \\
\text { Hill } \\
\text { Station }\end{array}$ & $\begin{array}{l}\text { Weepecket } \\
\text { Station }\end{array}$ & $\begin{array}{c}\text { Round Hill } \\
\text { Station at } \\
u_{*}=3.2 \mathrm{~cm} \mathrm{~s}^{-1}\end{array}$ & $\begin{array}{l}\text { Weepecket } \\
\text { Station at } \\
u_{*}=2.9 \mathrm{~cm} \mathrm{~s}^{-1}\end{array}$ \\
\hline SPM & 1.79 & 1.55 & $8.69 \times 10^{1}$ & $2.37 \times 10^{2}$ \\
\hline Chl a & 1.87 & 1.57 & $4.23 \times 10^{3}$ & $1.28 \times 10^{4}$ \\
\hline Bacteria & 0.28 & 0.72 & $3.00 \times 10^{11}$ & $6.54 \times 10^{11}$ \\
\hline HNan & 0.36 & 0.25 & $3.87 \times 10^{9}$ & $4.21 \times 10^{9}$ \\
\hline PNan & nd & 1.47 & nd & $1.45 \times 10^{9}$ \\
\hline Euglenoid flagellates & 0.37 & nd & nd & nd \\
\hline Oligotrich ciliates & 0.36 & 0.34 & $1.91 \times 10^{5}$ & $2.68 \times 10^{5}$ \\
\hline Scuticociliates & 0.36 & 0.89 & $1.97 \times 10^{5}$ & $5.62 \times 10^{5}$ \\
\hline Hypotrich ciliates & nd & 0.82 & nd & $3.65 \times 10^{5}$ \\
\hline Navicula distans & 1.45 & 0.40 & $8.02 \times 10^{6}$ & $1.30 \times 10^{7}$ \\
\hline Navicula transitans & 1.59 & 0.90 & $1.46 \times 10^{6}$ & $2.50 \times 10^{6}$ \\
\hline Pleurosigma sp. & 1.71 & 1.23 & $2.08 \times 10^{6}$ & $1.76 \times 10^{6}$ \\
\hline Nitzschia spp. & 2.10 & 1.58 & $6.03 \times 10^{5}$ & $7.02 \times 10^{6}$ \\
\hline
\end{tabular}

Table 3. Measurements from surficial $2 \mathrm{~mm}$ of sediment cores collected during slack low water at Round Hill Station on days of Sea Carousel experiment (11 August 2000) and sampling during tidal acceleration (31 August 2000). HNan = heterotrophic nanoflagellates; PNan = pigmented nanoflagellates. Sample size: $\mathrm{POM}, \mathrm{n}=2$; cells, $\mathrm{n}=3$; chl $a, \mathrm{n}=4$; error estimates $\pm 1 \mathrm{SE}$

\begin{tabular}{|c|c|c|}
\hline & $\begin{array}{l}\text { Sea Carousel } \\
\text { experiment }\end{array}$ & $\begin{array}{l}\text { Sampling during } \\
\text { tidal acceleration }\end{array}$ \\
\hline POM (mass fraction) & 0.039 & 0.024 \\
\hline Chl a ( $\mu g^{-1}$, dry wt) & $21.10( \pm 3.21)$ & $12.87( \pm 2.80)$ \\
\hline Bacteria (cells ml ${ }^{-1}$ ) & $1.14( \pm 0.17) \times 10^{9}$ & $2.51( \pm 0.28) \times 10^{9}$ \\
\hline HNan (cells ml ${ }^{-1}$ ) & $9.09( \pm 0.70) \times 10^{5}$ & $1.61( \pm 0.18) \times 10^{6}$ \\
\hline PNan (cells ml ${ }^{-1}$ ) & $2.30( \pm 0.55) \times 10^{5}$ & $7.50( \pm 0.86) \times 10^{5}$ \\
\hline Euglenoid flagellates & 0 & $1.70( \pm 0.36) \times 10^{3}$ \\
\hline $\begin{array}{l}\text { Oligotrich ciliates } \\
\left(\text { cells } \mathrm{ml}^{-1}\right)\end{array}$ & $60( \pm 6)$ & $79( \pm 20)$ \\
\hline $\begin{array}{l}\text { Scuticociliates } \\
\left(\text { cells } \mathrm{ml}^{-1}\right)\end{array}$ & $1.09( \pm 0.23) \times 10^{3}$ & $787( \pm 194)$ \\
\hline $\begin{array}{l}\text { Hypotrich ciliates } \\
\left(\text { cells } \mathrm{ml}^{-1}\right)\end{array}$ & $694( \pm 391)$ & $806( \pm 246)$ \\
\hline $\begin{array}{l}\text { Navicula distans } \\
\left(\text { cells } \mathrm{ml}^{-1} \text { ) }\right.\end{array}$ & $1.84( \pm 0.44) \times 10^{4}$ & $1.30( \pm 0.23) \times 10^{3}$ \\
\hline $\begin{array}{l}\text { Navicula transitans } \\
\left(\text { cells ml }^{-1} \text { ) }\right.\end{array}$ & $2.48( \pm 0.39) \times 10^{3}$ & $1.45( \pm 0.25) \times 10^{3}$ \\
\hline $\begin{array}{l}\text { Pleurosigma sp. } \\
\text { (cells } \mathrm{ml}^{-1} \text { ) }\end{array}$ & $6.29( \pm 1.76) \times 10^{3}$ & $1.32( \pm 0.25) \times 10^{3}$ \\
\hline $\begin{array}{l}\text { Nitzschia spp. } \\
\left(\text { cells } \mathrm{ml}^{-1}\right)\end{array}$ & $1.27( \pm 0.37) \times 10^{3}$ & $1.12( \pm 0.10) \times 10^{3}$ \\
\hline
\end{tabular}

ticociliates, 2.2 for HNan, and 1.4 for bacteria (Fig. 9). Absolute concentrations, however, of some of these taxa in the boundary-layer remained low; e.g. $<10$ cells $\mathrm{ml}^{-1}$ for the ciliates and euglenoids.

\section{DISCUSSION}

\section{Sediment resuspension and hydrography}

Differences in sediment-resuspension dynamics between the 2 sites can be explained by differing sediment composition and hydrography. Round Hill Station has a larger grain size (predominantly sand compared to silt at Weepecket Station), higher bulk density and lower porosity. Furthermore, surficial sediment at Round Hill had only onethird of the \%POM and one-quarter of the chl $a$ of Weepecket sediment (compare Table 3 with values in Shimeta et al. 2002), which is consistent with a sandier sediment at Round Hill. Accordingly, the bulk sediment at Round Hill had a higher $u_{* \text { crit }}$ for resuspension and a lower cumulative resuspension in the Sea Carousel (measured as change in total SPM). Furthermore, in agreement with the Sea Carousel measurements, there tended to be less SPM in the benthic boundary-layer at Round Hill Station. We measured 4 to $9 \mathrm{mg} \mathrm{l}^{-1}$ at Round Hill (Fig. 9B), whereas SPM ranged from 5 to $55 \mathrm{mg} \mathrm{l}^{-1}$ at Weepecket Station (Shimeta \& Sisson 1999, Shimeta et al. 2002) and similar values were reported for other sites in the silty region of Buzzards Bay (Rhoads 1973).

The 2 sites were similar, however, in that they appeared to have organicrich, flocculent surficial sediments that resuspended under weak flow. At Round Hill, the floc-layer resuspension was evident from the increase in suspended \%POM that occurred at $u_{*}=$ $0.19 \mathrm{~cm} \mathrm{~s}^{-1}$ in both the Sea Carousel and the natural sampling of the benthic boundary-layer. Floc-layer resuspension was identified at Weepecket Station from a similar peak of \% POM in the Sea 

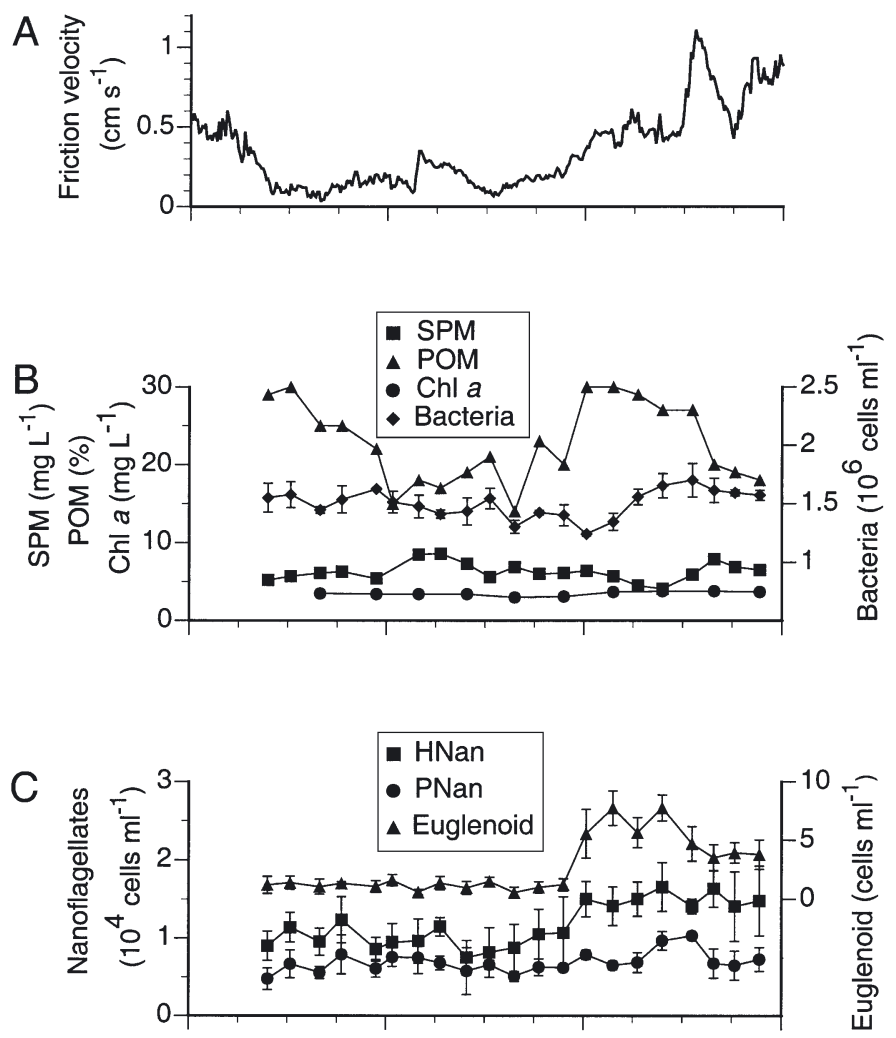

D
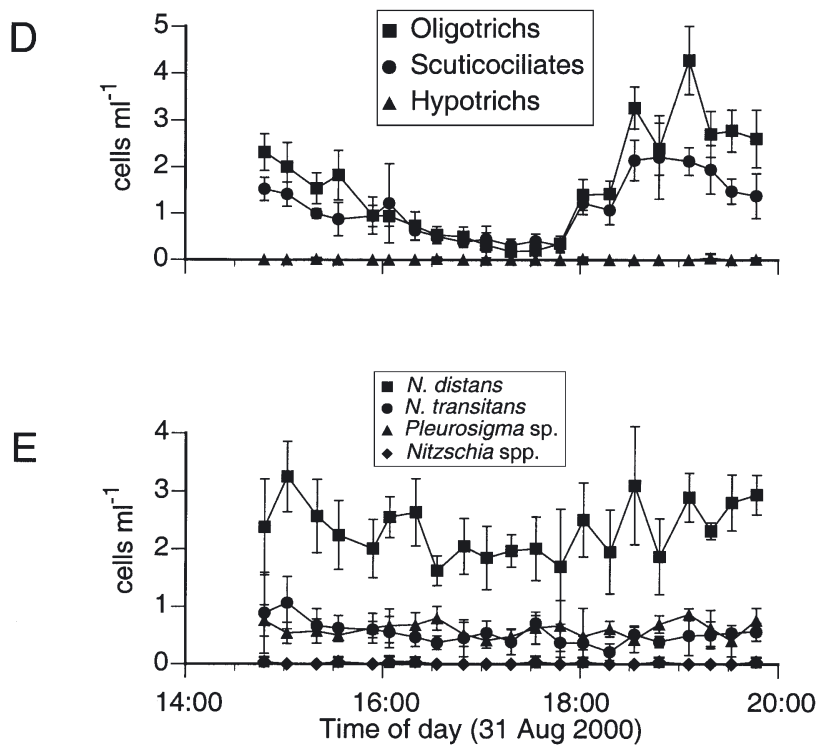

Fig. 9. Results from sampling the benthic boundary-layer $5 \mathrm{~cm}$ above the sea bottom at Round Hill on 31 August 2000 during slack low water and the flooding-tide acceleration. Where shown, error bars around means are SE and $n=3$; otherwise, $n=1$. (A) Friction velocity. (B) Suspended particulate matter (SPM), fraction composed of particulate organic matter (POM), chl $a$, and bacteria. (C) Nanoflagellates. HNan = heterotrophic nanoflagellates; PNan = pigmented nanoflagellates. (D) Ciliates. (E) Diatoms. Taxonomic groups showing no evidence of resuspension are excluded
Carousel at $u_{*}=0.25$ to $0.34 \mathrm{~cm} \mathrm{~s}^{-1}$ (Shimeta et al. 2002). Low-density, organic-rich flocculent layers have been observed in other sandy and fine-grained habitats (e.g. Jago \& Jones 1998, Maa et al. 1998).

At each station, the tidal periodicity in near-bottom light transmittance was consistent with a turbidity cloud that settled during some slack tides (reducing the near-bottom light transmittance), and mixed higher into the water column when tidal currents were strong (increasing the near-bottom light transmittance). The observed clearing of the boundary-layer during strong flow could occur if resuspension were limited to a finite amount of material coming off the bed. Similar cycles of near-bottom turbidity, including peak turbidity at slack tides (Figs. $3 \& 4$ ), and similar interpretations were reported for Weepecket Station and other sites in Buzzards Bay by Rhoads (1973), Rhoads et al. (1975), Roman \& Tenore (1978), and Shimeta \& Sisson (1999), and for the Elbe estuary in Germany by Eisma et al. (1994).

The period of the turbidity cycle and thus the frequency of resuspension, however, differed between the 2 stations and may be related to hydrography. At Round Hill, resuspension occurred only once during each tidal cycle, i.e. during the flooding current. The boundary-layer reached maximal clarity at slack high water, followed by steadily increasing near-bottom turbidity as material settled throughout the ebbing tide and slack low water. This frequency of resuspension may be explained by the fact that, at this site, the friction velocity of flooding currents was generally almost twice as strong as that of ebbing currents. Rhoads (1973) and Rhoads et al. (1975) reported similar results for other sites further in Buzzards Bay, where resuspension occurred only once during each tidal cycle, and maximal near-bottom turbidity was at slack low water. Our own data from a current meter near Rhoads's stations also showed stronger flooding currents than ebbing currents (Shimeta 1999), similar to Round Hill Station. In contrast, resuspension at Weepecket occurred twice during each tidal cycle, i.e. during both flooding and ebbing currents, while settling occurred during every slack water period between, and maximal near-bottom turbidities occurred soon after slack high water and after slack low water. Accordingly, at this site, the flooding and ebbing currents were generally more similar in strength.

\section{Resuspension of protists}

The frequency of cell-resuspension events differed between the sites, but at each site agreed with the sediment-resuspension frequency discussed above, based on near-bottom turbidity. At Round Hill, sediment and 
cells resuspended only once during each tidal cycle, i.e. on the flooding current, and they settled during ebbing tide and slack low water. (We caution that the cell-resuspension data are from only 2 days, Figs. 6 \& 9 , but they are consistent with 5 days of turbidity data, Fig. 3.) At Weepecket, in contrast, sediment and cells resuspended twice during each tidal cycle, i.e. on both flooding and ebbing currents, and they settled at the slack periods between (Shimeta \& Sisson 1999, Shimeta et al. 2002). As with sediment resuspension results, the cumulative cell resuspension in the Sea Carousel was less at Round Hill than at Weepecket. Together, these results suggest that exchange of protists between the sedimentary and water-column communities at Round Hill Station occurs half as often and involves fewer cells than at Weepecket.

Both sites had a protist community that resuspended in weak flow with the floc-layer of sediment, but the taxonomic composition of this community differed. At Round Hill Station, this included HNan, euglenoid flagellates, oligotrich ciliates, and scuticociliates, all resuspending at $u_{*}=0.36 \mathrm{~cm} \mathrm{~s}^{-1}$. These groups are commonly epibenthic, being abundant at the sediment-water interface and on sinking aggregates (e.g. Patterson et al. 1989, Caron 1991, Zimmermann-Timm et al. 1998). They may be attached to particles in the floc-layer, or only loosely associated with the sediment, or responding behaviorally to flow forces by swimming into the boundary-layer. Similarly at Weepecket Station, cells resuspending with the floc-layer included HNan and oligotrich ciliates (at $u_{*}=0.25$ to $0.34 \mathrm{~cm}$ $\mathrm{s}^{-1}$ ), but not the euglenoids or scuticociliates. The lack of euglenoid resuspension is explained simply by their having been undetectable in the sediment at Weepecket. Their distribution was evidently patchy in the bay, because although they were undetectable at Weepecket on 29 and 30 August 2002, there were 1700 cells ml ${ }^{-1}$ in the sediment at Round Hill on the following day. The fact that scuticociliates did not resuspend with the floc-layer at Weepecket (where their $u_{*_{\text {crit }}}$ was much higher, at 0.89 to $1.3 \mathrm{~cm} \mathrm{~s}^{-1}$ ) may have been due to a differing species composition and associated behaviors or positioning in the sediment. At Weepecket, the scuticociliates were dominated by Uronema spp. and Cyclidium spp., whereas at Round Hill there was also a very abundant Cohnilembus sp. Furthermore, the diatom Navicula distans resuspended with the floc-layer at Weepecket but not at Round Hill, where its threshold was more similar to the bulk sediment, possibly reflecting a difference in cell position, mucilage production, or sediment fabric.

Several taxa that resuspended at Weepecket Station had higher thresholds at Round Hill Station, or did not resuspend under any of the conditions measured there, including hypotrich ciliates, PNan, and all of the diatom taxa reported. The discrepancy for hypotrich ciliates again may have been due to species composition. The hypotrichs at Round Hill were dominated by a small Euplotes sp. (likely the E. minuta isolated there by Shimeta et al. 2001), whereas at Weepecket they were predominantly larger euplotid species. The fact that diatoms had higher resuspension thresholds at Round Hill may be related to the higher threshold for bulk sediment erosion, because at each site most diatom thresholds (as well as chl a) generally matched the threshold for bulk sediment. The dynamics of diatom resuspension appeared to be more dependent on local sediment properties than were the dynamics of protozoan resuspension.

The fact that, at both sites, resuspension thresholds for the various protistan groups were not all identical implies that taxa will resuspend in sequence as tidal currents accelerate. Sequential resuspension was documented at Weepecket Station during natural tidal acceleration (Shimeta et al. 2002). At Round Hill, under the same sampling procedure, cells associated with the floc-layer all resuspended simultaneously, but the flow never reached the threshold to resuspend diatoms. However, we infer that the full sequence would result under a stronger current. The sequential-resuspension phenomenon should cause the species makeup of the cell assemblage that exchanges between the benthos and plankton to depend on the maximal bed shear stress of a given tidal current, and it should therefore vary with the spring-neap cycle and with atmospheric forcing. Interestingly, the sites differ in that the species makeup of resuspending cells at Round Hill is less sensitive to variations in maximal flow strength than it is at Weepecket. At Round Hill, protists fell into 2 fairly distinct groups based on resuspension thresholds: the floc-layer group (HNan, euglenoid flagellates, oligotrichs, and scuticociliates) and the bulk-sedimentassociated group (diatoms). At Weepecket, in contrast, there was a more continuous gradation of resuspension thresholds among taxa (Shimeta et al. 2002), and therefore small differences in maximal flow strength should make more of a difference in determining which species will resuspend.

Protist resuspension may have strong impacts on microbial food-web ecology in the water column and sediments, by linking the planktonic and benthic communities. The large fluctuations of cell concentrations observed here in the benthic boundary-layer during tidal acceleration (up to $24 \times$ for oligotrichs; Fig. 9) should alter community structure, contact rates between predators and prey, competition, and exposure to physical and chemical conditions, and it should affect the seeding of the water column with surfaceassociated protists that colonize suspended aggregates (e.g. Caron 1991, Zimmermann-Timm et al. 1998, 
Shimeta et al. 2002). Feeding and growth rates of suspension-feeding protozoa can be altered as they move through regions of differing flow strength (e.g. Shimeta et al. 1995, 2001, Garstecki \& Wickham 2001). Data presented here suggest that the frequency and extent of these dynamics in the ecology of protists in coastal habitats depend on physical-environmental factors such as local sediment characteristics and hydrography, as well as local taxonomic composition. Temporal variation of resuspension dynamics might be important too, e.g. if sediment cohesiveness and erosion thresholds change seasonally.

Acknowledgements. We thank C. Cottrill, K. Hippe, D. Lambkin, R. Murphy, J. Sisson, V. Starczak, and N. Trowbridge for assistance in the field and/or lab; C. A. Zimmer, D. Anderson, R. Francois, and the director of the Rinehart Coastal Research Center (WHOI) for use of facilities and equipment; and the captain of the R/V 'Asterias'. The manuscript was improved with comments from 3 anonymous reviewers. Supported by NSF grant OCE-9711441 (J.S.), grants from the Rinehart Coastal Research Center (J.S., S.E.B.), a WHOI Postdoctoral Scholarship (S.E.B.), and a Hackman fellowship from F\&M College (S.L.K.). This is WHOI contribution 10837.

\section{LITERATURE CITED}

Amos CL, Daborn GR, Christian H, Atkinson A, Robertson A (1992a) In situ erosion measurements on fine-grained sediments from the Bay of Fundy. Mar Geol 108:175-196

Amos CL, Grant J, Daborn GR, Black K (1992b) Sea carousel-a benthic, annular flume. Estuar Coast Shelf Sci 34:557-577

Amos CL, Sutherland TF, Radzijewski B, Doucette M (1996) A rapid technique to determine bulk density of finegrained sediments by X-ray computed tomography. J Sed Res 66:1023-1039

Baillie PW, Welsh BL (1980) The effect of tidal resuspension on the distribution of intertidal epipelic algae in an estuary. Estuar Coast Mar Sci 10:165-180

Banta GT, Giblin AE, Hobbie JE, Tucker J (1995) Benthic respiration and nitrogen release in Buzzards Bay, Massachusetts. J Mar Res 53:107-135

Caron DA (1991) Heterotrophic flagellates associated with sedimenting detritus. In: Patterson DJ, Larsen J (eds) The biology of free-living heterotrophic flagellates. Clarendon Press, Oxford, p 77-92

Caron DA, Finlay BJ (1994) Protozoan links in food-webs. In: Hausmann K, Hülsmann N (eds) Progress in protozoology. Springer-Verlag, Berlin, p 125-130

de Jonge VN, van Beusekom JEE (1992) Contribution of resuspended microphytobenthos to total phytoplankton in the Ems estuary and its possible role for grazers. Neth J Sea Res 30:91-105

de Jonge VN, van Beusekom JEE (1995) Wind- and tideinduced resuspension of sediment and microphytobenthos from tidal flats in the Ems estuary. Limnol Oceanogr 40: 766-778

Demers S, Therriault JC, Bourget E, Bah A (1987) Resuspension in the shallow sublittoral zone of a macrotidal estuarine environment: wind influence. Limnol Oceanogr 32: $327-339$
Eisma D, Chen S, Li A (1994) Tidal variations in suspended matter floc size in the Elbe river and Dollard estuaries. Neth J Aquat Ecol 28:267-274

Epstein SS (1997a) Microbial food-webs in marine sediments. I. Trophic interactions and grazing rates in 2 tidal flat communities. Microb Ecol 34:188-198

Epstein SS (1997b) Microbial food-webs in marine sediments. II. Seasonal changes in trophic interactions in a sandy tidal flat community. Microb Ecol 34:199-209

Fanning KA, Carder KL, Betzer PR (1982) Sediment resuspension by coastal waters: a potential mechanism for nutrient re-cycling on the ocean's margins. Deep-Sea Res 29: 953-965

Fenchel T (1987) Ecology of protozoa. Springer-Verlag, Berlin

Fuller CM, Butman CA (1988) A simple technique for finescale, vertical sectioning of fresh sediment cores. J Sediment Petrol 58:763-768

Garstecki TR, Wickham SA (2001) Effects of resuspension and mixing on population dynamics and trophic interactions in a model benthic microbial food-web. Aquat Microb Ecol 25:281-292

Garstecki T, Verhoeven R, Wickham SA, Arndt H (2000) Benthic-pelagic coupling: a comparison of the community structure of benthic and planktonic heterotrophic protists in shallow inlets of the southern Baltic. Freshw Biol 45: 147-167

Hopkinson CS (1987) Nutrient regeneration in shallow-water sediments of the estuarine plume region of the nearshore Georgia Bight, USA. Mar Biol 94:127-142

Jago CF, Jones SE (1998) Observation and modelling of the dynamics of benthic fluff resuspended from a sandy bed in the southern North Sea. Cont Shelf Res 18:1255-1282

Lucas CH, Banham C, Holligan PM (2001) Benthic-pelagic exchange of microalgae at a tidal flat. 2. Taxonomic analysis. Mar Ecol Prog Ser 212:39-52

Maa JPY, Sanford L, Halka JP (1998) Sediment resuspension characteristics in Baltimore Harbor, Maryland. Mar Geol 146:137-145

McNichol AP, Lee C, Druffel ERM (1988) Carbon cycling in coastal sediments: 1 . A quantitative estimate of the remineralization of organic carbon in the sediments of Buzzards Bay, MA. Geochim Cosmochim Acta 52:1531-1543

McNichol AP, Druffel ERM, Lee C (1991) Carbon cycling in coastal sediments: 2. An investigation of the sources of $\mathrm{SCO}_{2}$ to pore water using carbon isotopes. In: Baker RA (ed) Organic substances and sediment in water, Vol 2. Processes and analytical. Lewis Publishers, Chelsea, p 249-272

Moore JR (1963) Bottom sediment studies, Buzzards Bay, Massachusetts. J Sediment Petrol 33:511-558

Parsons TR, Maita Y, Lalli CM (1984) A manual of chemical and biological methods for seawater analysis. Pergamon Press, New York

Patterson DJ, Larsen J, Corliss JO (1989) The ecology of heterotrophic flagellates and ciliates living in marine sediments. Prog Protistol 3:185-277

Porter KG, Feig YS (1980) The use of DAPI for identifying and counting aquatic microflora. Limnol Oceanogr 25:943-948

Raaphorst WV, Malschaert H, Haren HV (1998) Tidal resuspension and deposition of particulate matter in the Oyster Grounds, North Sea. J Mar Res 56:257-291

Rhoads DC (1973) The influence of deposit-feeding benthos on water turbidity and nutrient recycling. Am J Sci 273:1-22

Rhoads DC, Tenore K, Browne M (1975) The role of resuspended bottom mud in nutrient cycles of shallow embayments. In: Cronin LE (ed) Estuarine research, Vol 1. Academic Press, New York, p 563-579 
Ritzrau W, Graf G (1992) Increase of microbial biomass in the benthic turbidity zone of Kiel Bight after resuspension by a storm event. Limnol Oceanogr 37:1081-1086

Roman MR (1978) Tidal resuspension in Buzzards Bay, Massachusetts. II. Seasonal changes in the size distribution of chlorophyll, particle concentration, carbon and nitrogen in resuspended particulate matter. Estuar Coast Mar Sci 6: $47-53$

Roman MR (1980) Tidal resuspension in Buzzards Bay, Massachusetts, III. Seasonal changes of nitrogen and carbon:nitrogen ratios in seston and zooplankton. Estuar Coast Mar Sci 11:9-16

Roman MR, Tenore KR (1978) Tidal resuspension in Buzzards Bay, Massachusetts. I. Seasonal changes in the resuspension of organic carbon and chlorophyll a. Estuar Coast Mar Sci 6:37-46

Sanders HL (1958) Benthic studies in Buzzards Bay. I. Animalsediment relationships. Limnol Oceanogr 3:245-258

Sanford LP, Maa JPY (2001) A unified erosion formulation for fine sediments. Mar Geol 179:9-23

Shaffer GP, Sullivan MJ (1988) Water column productivity attributable to displaced benthic diatoms in well-mixed shallow estuaries. J Phycol 24:132-140

Shimeta J (1999) Tidal resuspension of protists in Buzzards Bay; alterations of community structure and implications for food-web dynamics. Woods Hole Oceanogr Inst Tech Rep Ser WHOI-99-04:205-210

Shimeta J, Sisson JD (1999) Taxon-specific tidal resuspension of protists into the subtidal benthic boundary layer of a coastal embayment. Mar Ecol Prog Ser 177:51-62

Shimeta J, Jumars PA, Lessard EJ (1995) Influences of turbulence on suspension feeding by planktonic protozoa; experiments in laminar shear fields. Limnol Oceanogr 40: 845-859

Shimeta J, Starczak VR, Ashiru OM, Zimmer CA (2001) Influ-

Editorial responsibility: Evelyn \& Barry Sherr (Contributing

Editors), Corvallis, Oregon, USA ences of benthic boundary-layer flow on feeding rates of ciliates and flagellates at the sediment-water interface. Limnol Oceanogr 46:1709-1719

Shimeta J, Amos CL, Beaulieu SE, Ashiru OM (2002) Sequential resuspension of protists by accelerating tidal flow: Implications for community structure in the benthic boundary layer. Limnol Oceanogr 47:1152-1164

Sternberg RW (1968) Friction factors in tidal channels with differing bed roughness. Mar Geol 6:243-260

Suderman K, Thistle D (1998) Adult female harpacticoid copepods maintain their energy reserves by feeding while suspended during storms. Mar Ecol Prog Ser 164:245-252

Sutherland TF, Amos CL, Grant J (1998) The effect of buoyant biofilms on the erodibility of sublittoral sediments of a temperate microtidal estuary. Limnol Oceanogr 43: 225-235

Thomsen L, Gust G (2000) Sediment erosion thresholds and characteristics of resuspended aggregates on the western European continental margin. Deep-Sea Res 47:1881-1897

Utermöhl H (1958) Zur Vervollkommnung der quantitativen Phytoplankton-Methodik. Int Ver Limnol 9:1-39

Wainright SC (1987) Stimulation of heterotrophic microplankton production by resuspended marine sediments. Science 238:1710-1712

Wainright SC (1990) Sediment-to-water fluxes of particulate material and microbes by resuspension and their contribution to the planktonic food-web. Mar Ecol Prog Ser 62: 271-281

Widdows J, Brinsley MD, Salkeld PN, Lucas CH (2000) Influence of biota on spatial and temporal variation in sediment erodability and material flux on a tidal flat (Westerschelde, The Netherlands). Mar Ecol Prog Ser 194:23-37

Zimmermann-Timm H, Holst H, Müller S (1998) Seasonal dynamics of aggregates and their typical biocoenosis in the Elbe Estuary. Estuaries 21:613-621

Submitted: October 16, 2002; Accepted: August 21, 2003

Proofs received from author(s): September 9, 2003 